\title{
Recombinant chromosome 4 in two fetuses - case report and literature review
}

\author{
Yi Wu ${ }^{1,2,3 \dagger}$, Yanlin Wang ${ }^{1 \dagger}$, Shi Wu Wen ${ }^{2,3,4}$, Xinrong Zhao ${ }^{1}$, Wenjing Hư ${ }^{5}$, Chunmin Liu', Li Gao ${ }^{1}$, Yan Zhang ${ }^{1}$, \\ Shan Wang ${ }^{1}$, Xingyu Yang ${ }^{6}$, Biwei $\mathrm{He}^{6}$ and Weiwei Cheng ${ }^{1 *}$
}

\begin{abstract}
Background: Recombinant chromosome 4 syndrome (rec 4 syndrome) is a rare genetic disorder, predominately resulting from a parental pericentric inversion of chromosome 4. To date, a total of 18 cases of rec (4) syndrome were published in literature. We report the first kindred of rec (4) syndrome analyzed using copy number variation sequencing (CNV-seq).

Results: A woman with two adverse fetal outcomes was described in the present study. The first fetus presented with severe intrauterine growth restriction, hyposarca, hydrothorax and ascites. The CNV-seq revealed a dup 4q and del $4 p$. The second fetus presented with cardiovascular disease of ventricular septal defect, overriding aorta and persistent trunk. The CNV-seq revealed a dup $4 p$ and del 4q. We collected 18 rec (4) cases through literature review. Genotype-phenotype correlation analysis was also performed.

Conclusion: Recombinant 4 syndrome is a rare genetic disorder. It should be divided into two categories according to the alternative recombinant types. The clinical manifestations of rec (4) cases with dup $4 q$ and del $4 p$ are consistent with the Wolf-Hirschhorn syndrome. For cases harboring dup $4 p$ and del $4 q$, the high incidence of congenital heart disease is prominent.
\end{abstract}

Keywords: Recombinant (4) syndrome, Congenital heart disease, Prenatal diagnosis, Rare genetic disorder

\section{Background}

Imbalances of chromosome 4 include various types of constitutional abnormalities, including Wolf-Hirschhorn syndrome (WHS, 4p- syndrome) [1], 4q- syndrome [2], dup $4 \mathrm{p}$ syndrome [3] and dup $4 \mathrm{q}$ syndrome [4]. Amongst the constitutional anomalies of chromosome 4, the rarest condition is the "recombinant chromosome 4 syndrome"-rec (4) syndrome, with concomitant deletion and duplication on the same chromosome 4, resulting from a pericentric inversion in a parent [2]. The genetic condition of recombinant (4) syndrome is so rare that its incidence in population has not been estimated. This condition was initially called dup $4 \mathrm{p}$ syndrome, because only large duplications of $4 \mathrm{p}$ were observed by the conventional karyotyping, while the small $4 \mathrm{q}$ terminal deletions were missed due to low resolution [5]. More

\footnotetext{
* Correspondence: wwcheng29@shsmu.edu.cn

${ }^{\dagger}$ Yi Wu and Yanlin Wang contributed equally to this work.

${ }^{1}$ Prenatal Diagnostic Center, International Peace Maternity \& Child Health

Hospital, School of Medicine, Shanghai JiaoTong University, Shanghai, China

Full list of author information is available at the end of the article
}

recently, molecular techniques have led to the discovery of several dup $4 \mathrm{p}$ syndrome cases which were actually inverted $4 \mathrm{p}$ duplication combined with the $4 \mathrm{q}$ terminal deletions. Hence, some authors also called it "inv dup del 4" [6].

Here, we report on a woman who had two adverse pregnancy outcomes, with two different types of chromosome 4 recombinants. The CNV-seq results of both fetuses revealed the same breakpoints on the chromosome 4, involving 4p15.2 and 4q32.3. One fetus was rec (4) dup (4p) del (4q), the other was rec (4) dup $(4 q)$ del $(4 p)$. The size of deletion and duplication distal to breakpoints are very similar to each other (both approximately $23 \mathrm{Mb}$ ). The breakpoint of $4 \mathrm{q} 32.3$ on the long arm of chromosome 4 has never been reported among rec (4) cases. Also, a genotype-phenotype correlation study was performed between the present cases and previously reported cases of rec (4), to further delineate the relationship of specific chromosomal breakpoints with clinical features. 


\section{Methods}

\section{Patients}

\section{Fetus 1}

A 33-year-old G1P0 pregnant woman was referred to the Prenatal Diagnosis center of International Peace Maternity \& Child Health Hospital at 11 weeks of gestation due to increased fetal nuchal translucency (NT $10 \mathrm{~mm}$ ). The couple was non-consanguineous and this pregnancy was naturally conceived. CVS sampling and cytogenetic analysis were suggested but declined. At 16 weeks, ultrasound findings revealed severe fetal hyposarca and intrauterine growth restriction (IUGR), with the fetal biometry $<10$ th centile. Parents then accepted amniocentesis. After signing the informed consent, both conventional karyotyping and copy number variation sequencing ( $\mathrm{CNV}$-seq) were performed on amniocytes. Parental karyotypes were also tested. There were no gross abnormal findings in fetal and parental karyotypes (Fig. 1a, c and d). However, the fetal CNV-seq results were abnormal: arr [GRCh37] 4p15.2p16.3 (4001-23,300,000) $\times 1$, 4q32.3q35.2 (167040001-190,940,000) × 3(Fig. 2a). The fetal karyotyping was actually 46, XX, der (4), (qter $\rightarrow$ q32.3::p15.2 $\rightarrow$ qter), according to the ISCN (2016). The fetal chromosomal abnormalities were overlooked due to the poor quality of G-banding and low resolution. Ultrasound findings at 21 weeks revealed IUGR, hydrothorax $(4 \mathrm{~mm})$ and ascites (5 mm), increased nuchal fold (NF $12.7 \mathrm{~mm}$, septation was seen), hydrothorax and bilateral mild ventriculomegaly (left $7.1 \mathrm{~mm}$ and right $6.0 \mathrm{~mm}$ ) (seen in Fig. 3a, b and c). Fetal echocardiography was normal. Pregnancy was terminated at 24 weeks by the parental request.

\section{Fetus 2}

One year later, the woman came to our center again during her second pregnancy at 21 weeks of gestation due to fetal congenital heart disease (CHD). The family history was negative for CHD. Her second pregnancy was uneventful before 21 weeks with the NT $1.9 \mathrm{~mm}$ at 11 weeks. However, the radiologist suspected fetal CHD after the first fetal anomaly scan at 21 weeks. Fetal echocardiography was offered shortly after the anomaly scan and revealed fetal ventricular septal defect, overriding aorta and persistent trunk (seen in Fig. 4a-d). The ultrasound findings of fetal anomaly scan also revealed increased nuchal fold (NF $9.3 \mathrm{~mm})$ and fetal ascites. Once again, the fetal a

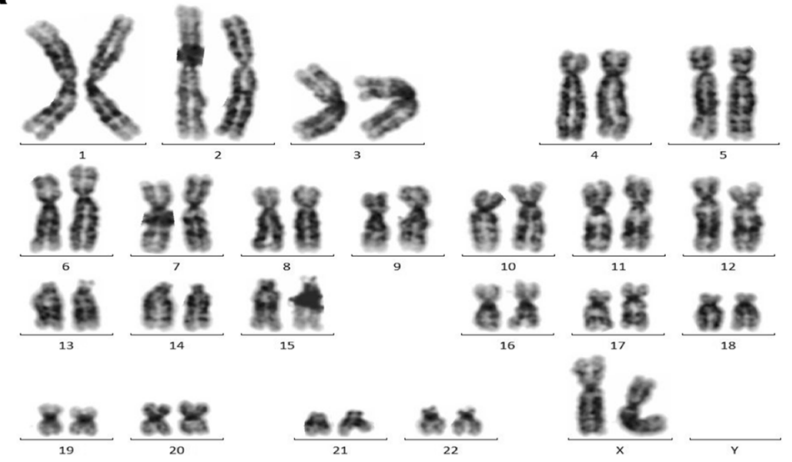

C

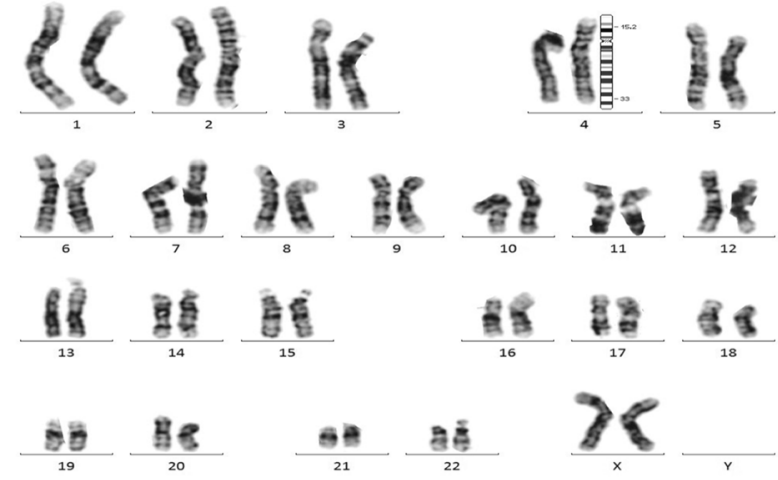

b

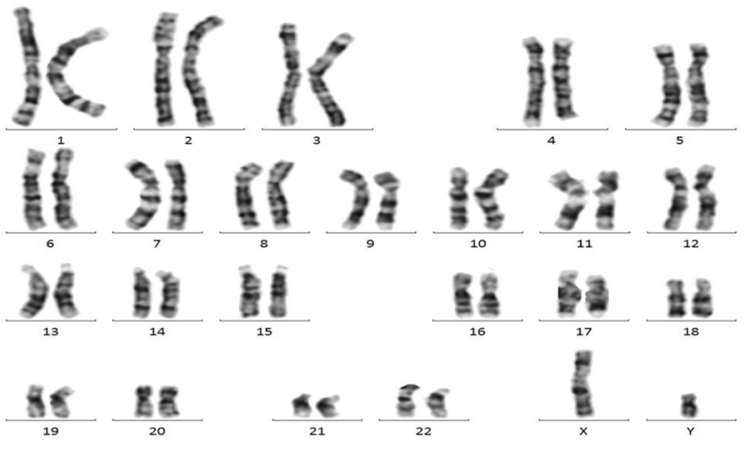

d
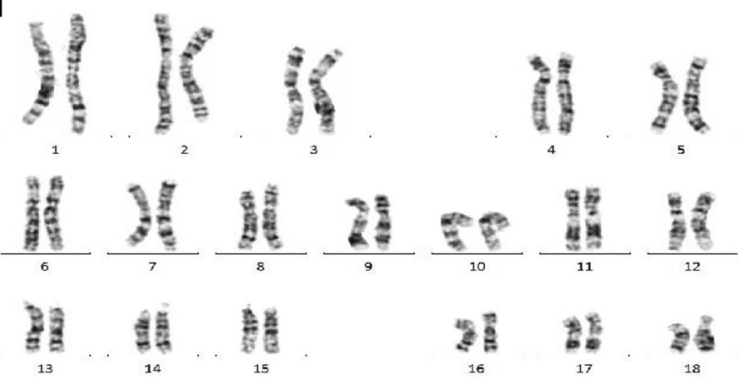

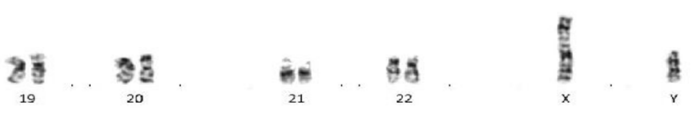

Fig. 1 karyotypes of fetuses and parents. a karyotyping of the first fetus; $\mathbf{b}$ : karyotyping of the second fetus; $\mathbf{c}$ and (d): results of karyotyping of the parents, respectively 

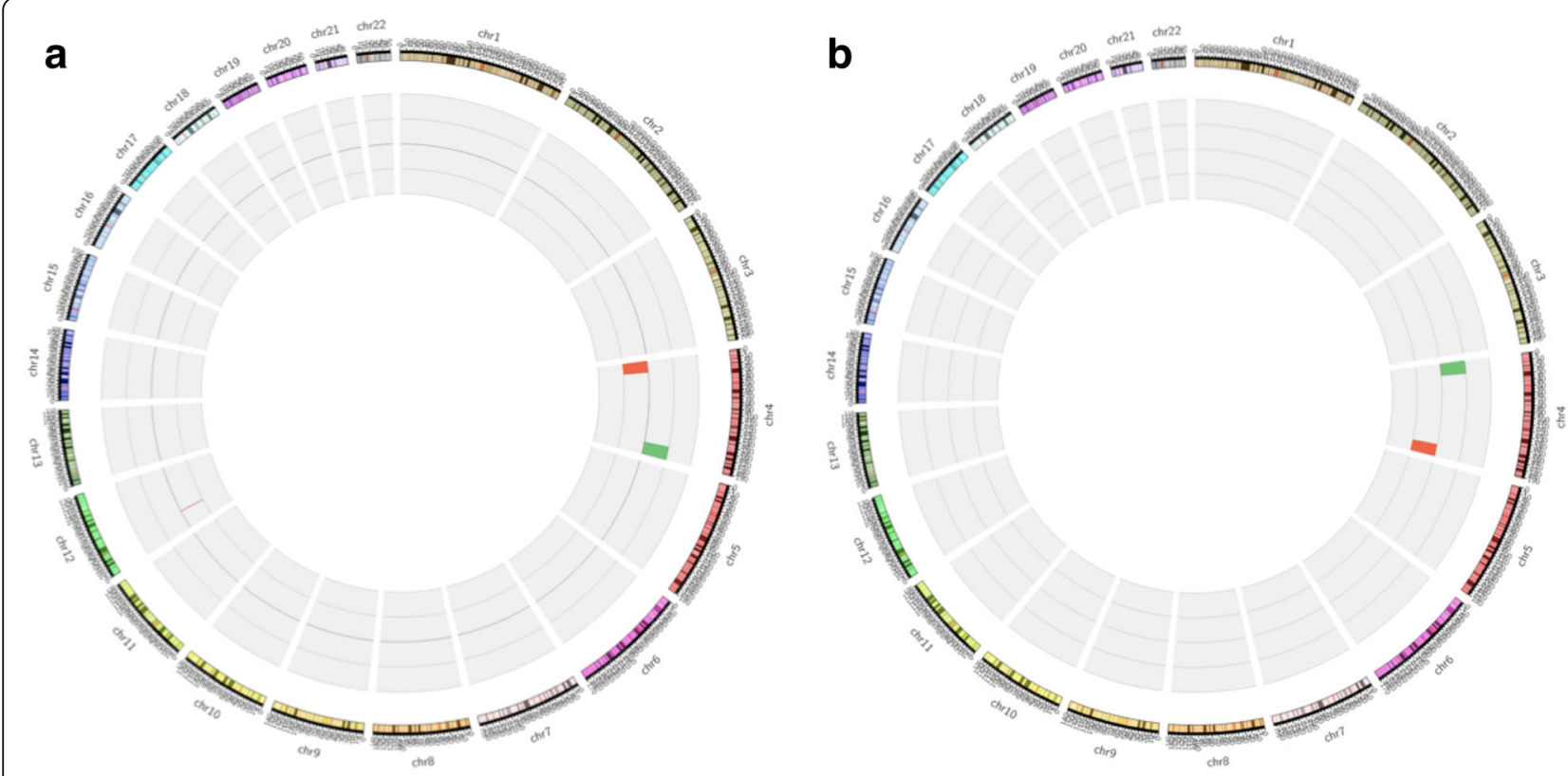

Fig. 2 CNV seq results of two fetuses. a CNV-seq result of fetus 1: arr [GRCh37] 4p15.2p16.3 (4001-23,300,000) × 1, 4q32.3 q35.2 (167040001$190,940,000) \times 3$. b CNV-seq result of fetus 2: arr [GRCh37] 4p15.2 p16.3(40001-23,320,000) ×3, 4q32.3 q35.2 $(167040001-190,940,000) \times 1$

karyotyping and CNV-seq were done after signing the informed consent. No gross abnormalities identified in fetal karyotype (Fig. 1b). However, the abnormal CNV-seq results for the second fetus were: arr [GRCh37] $4 \mathrm{p} 15.2 \mathrm{p} 16.3 \quad(40001-23,320,000) \times 3, \quad 4 \mathrm{q} 32.3 \mathrm{q} 35.2$ $(167040001-190,940,000) \times 1$, (Fig. 2b). The fetal karyotyping was reassessed as46, XY, der (4), $($ pter $\rightarrow$ q32.3p15.2 $\rightarrow$ pter), according to the ISCN (2016).Parental peripheral blood samples were tested by CNV-seq but no abnormalities were observed. Based on the two pregnancies, pericentric inversion of chromosome 4 in one of the parents was highly suspected. Fluorescence in situ hybridization (FISH) was suggested, but was declined. Parents decided to terminate the pregnancy at 24 weeks of gestation.

\section{Chromosome analysis}

Amniocentesis was performed to obtain the fetal samples after signing the informed consents. Peripheral blood samples were collected from both parents. Chromosome analysis was performed according to the standard protocol using G-banding.

\section{Copy number variation sequencing (CNV-seq)}

DNA libraries were constructed by transposase to fragment and add tag to each end of DNA fragments, and PCR amplified molecules subjected to massively parallel sequencing on the NextSeq 500 platform (Illumina, US). Plots of $\log 2$ [mean $\mathrm{CN}$ ratio] per bin (Y-axis) versus each $20 \mathrm{~kb}$ bin (X-axis) were generated for each of the 24 chromosomes. For reference, a $\log _{2}$ of 0 indicates a
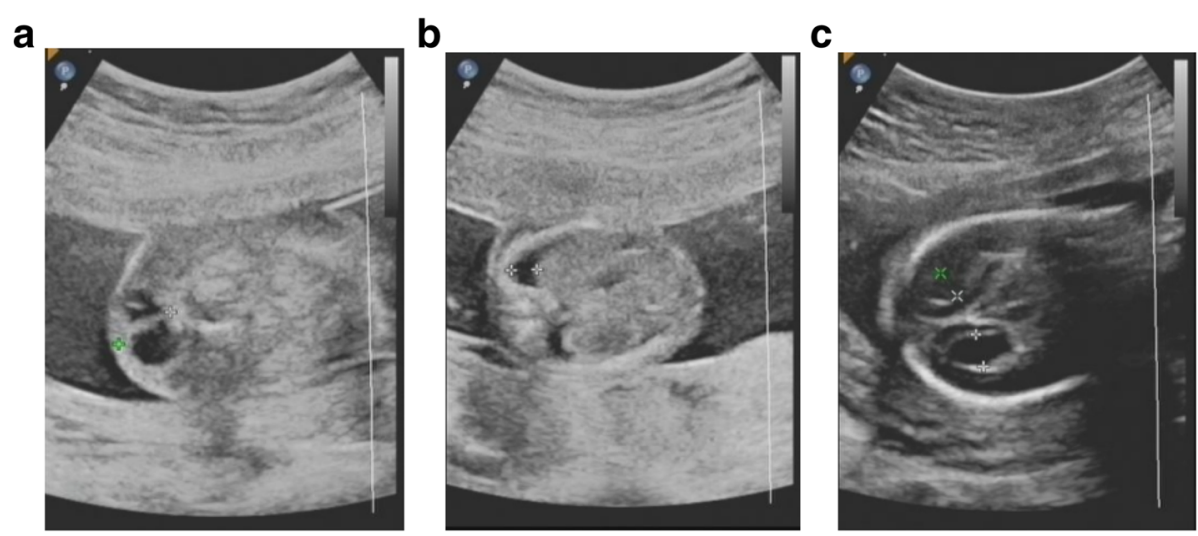

Fig. 3 ultrasound findings of the first fetus. a increased nuchal fold with septation; $\mathbf{b}$ hydrothorax; $\mathbf{c}$ bilateral mild ventriculomegaly 
a

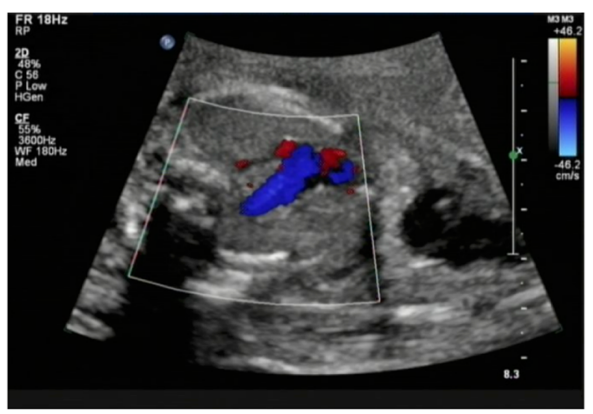

C

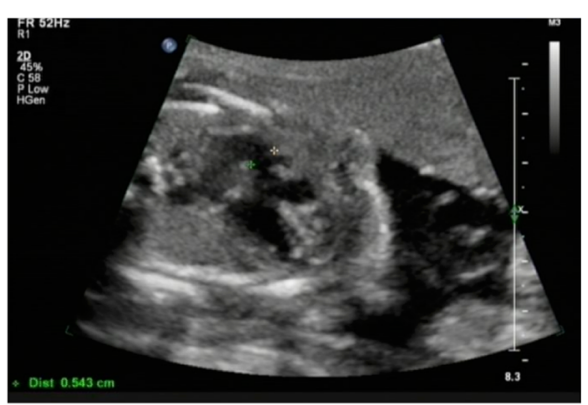

b

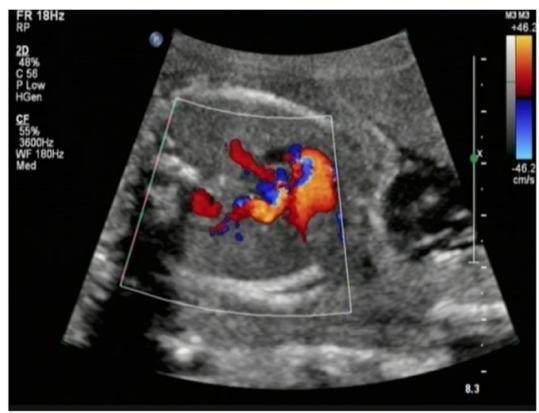

d

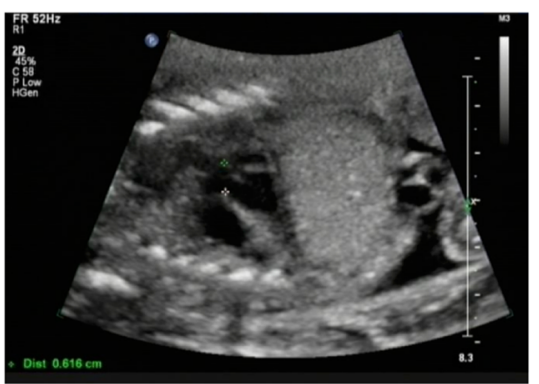

Fig. 4 fetal echocardiography of the second fetus. a three vessels views in fetal echocardiography; b persistent trunk; c and (d) ventricular septal defect

$\mathrm{CN}$ of 2.0 (disomy) while $\log _{2}$ values of 1.5 and 0.5 indicate a $\mathrm{CN}$ of 3.0 (duplication) and a $\mathrm{CN}$ of 1.0 (deletion), respectively. For reporting $\mathrm{CNVs}, \mathrm{CN}$ ranges of 2.9-3.1 for a duplication and $0.9-1.1$ for a deletion were used.

\section{Discussion}

Recombinant chromosome 4 syndrome (rec 4 syndrome) is a very rare genetic condition, primarily caused by a pericentric inversion of chromosome 4 in a parent $[2,7]$. A total of 18 rec (4) syndrome cases have been well-documented, showing different recombinant types and varying clinical presentations (17 in literature and 1 in DECIPHER database, Table 1) [5, 7-20]. Generally, a pericentric inversion will give rise to four types of gametes during the meiosis, including two balanced and two unbalanced [18, 21]. Balanced gametes, either the normal chromosome or the same inverted chromosome inherited from the parent, will generally develop into normal fetuses. However, unbalanced gametes are rather complex issues. During meiosis in carriers, a chromosome containing a large inverted segment and its normal homolog are predicted to form a homosynaptic inversion loop, in order to obtain optimal pairing of the matching segment. Any odd number of crossovers within the inversion loop leads to the production of two alternate recombinant chromosomes: in one chromosome the distal part of the short arm is duplicated and the distal part of the long arm is deleted; the opposite occurs to be short arm deletion and long arm duplication [7]. In our study, although FISH was refused by the parents, the constitutional chromosomal abnormalities occurred in two fetuses are most probably consistent with recombinant (4) syndrome. The breakpoints on long arm of chromosome 4 for two fetuses in the present study were different from any other previously reported cases. To the best of our knowledge, although it is within the range of $4 \mathrm{q} 28-4 \mathrm{q} 35$, it's the first time that the breakpoint of $4 \mathrm{q} 32.3$ among rec (4) syndrome cases is going to be reported.

According to the previous conclusion, duplicated segments are always longer than deleted ones in viable inv. dup del cases $[6,12,13]$. It sounds reasonable because a large deletion might be more deleterious than a large duplication. Embryos with a large deletion are most likely to suffer spontaneous miscarriages in the very early gestational ages. However, through literature review, we found three viable rec (4) cases with the recombinant type of a large deletion and a small duplication $[9,11,14]$. This finding might be explained by the vision that individuals have different tolerance to genetic deletions. Interestingly, we found all three viable cases with large deletion carried a large $4 \mathrm{p}$ deletion and a small $4 \mathrm{q}$ duplication. However, there was no viable rec (4) case with a large $4 \mathrm{q}$ deletion and a small $4 \mathrm{p}$ duplication. This observation suggests that large $4 \mathrm{q}$ deletion might be more deleterious than $4 p$ deletion. Large $4 q$ deletion might be lethal in early embryonic development and then lead to spontaneous miscarriages.

Rec (4) syndrome is primarily caused by the pericentric inversion from one of the parents. But, it is worth 
Table 1 clinical presentations of two types of recombinants

\begin{tabular}{|c|c|c|c|c|c|c|c|}
\hline \multirow[t]{2}{*}{ Authors } & \multirow[t]{2}{*}{ Sub-bands } & \multicolumn{5}{|l|}{ Clinicalpresentations } & \multirow{2}{*}{$\begin{array}{l}\text { Outcome and } \\
\text { annotations }\end{array}$} \\
\hline & & $\begin{array}{l}\text { Facial } \\
\text { dysmorphisism }\end{array}$ & $\begin{array}{l}\text { Growth and } \\
\text { development/mental delay }\end{array}$ & $\mathrm{CHD}$ & $\begin{array}{l}\text { Extremities } \\
\text { abnormailities }\end{array}$ & $\begin{array}{l}\text { Genital } \\
\text { abnormalities }\end{array}$ & \\
\hline Dup $4 q$ and del $4 p$ & (10 cases) & & & & & & \\
\hline $\begin{array}{l}\text { Narahara et al. } \\
1984 \text { [9] }\end{array}$ & p15.2q35 & $\begin{array}{l}\text { Microcephaly } \\
\text { frotal bossing } \\
\text { hypertelorism } \\
\text { epicanthic } \\
\text { folds } \\
\text { small chin }\end{array}$ & $\begin{array}{l}\text { Growth retardation } \\
\text { development delay }\end{array}$ & VSD & Sacral dimple & No & Live \\
\hline $\begin{array}{l}\text { de la Flor \& Guitart } \\
1987 \text { [10] }\end{array}$ & p16q31.3 & $\begin{array}{l}\text { Broad flat } \\
\text { nasal bridge } \\
\text { high forehead } \\
\text { hypertelorism } \\
\text { small chin } \\
\text { (Greek Helmet } \\
\text { appearence) }\end{array}$ & $\begin{array}{l}\text { Growth retardation } \\
\text { development delay }\end{array}$ & No & No & No & Live \\
\hline $\begin{array}{l}\text { Hirsch et al.1993 [11], } \\
\text { patient III-1 }\end{array}$ & p15.32q35 & $\begin{array}{l}\text { Flat nasal } \\
\text { bridge } \\
\text { prominent } \\
\text { forhead } \\
\text { small chin } \\
\text { hypertelorism } \\
\text { microcephaly } \\
\text { iris coloboma } \\
\text { retinal dysplasia }\end{array}$ & $\begin{array}{l}\text { Growth retardation } \\
\text { development delay }\end{array}$ & No & No & No & Live \\
\hline Wolf et al. 1994 [12] & $\mathrm{p} 13 \mathrm{q} 28$ & NA & NA & NA & NA & NA & Fetal demise \\
\hline Villa et al.1995 [13] & $\mathrm{p} 15.2 \mathrm{q} 28.2$ & $\begin{array}{l}\text { Greek warrior } \\
\text { helmet appearance } \\
\text { prominent forhead } \\
\text { hypertelorism } \\
\text { downslanting } \\
\text { palpebral fissures } \\
\text { epicanthal folds } \\
\text { small chin }\end{array}$ & Growth retardation & PDA & $\begin{array}{l}\text { Abnormal } \\
\text { fingers and } \\
\text { clubfeet }\end{array}$ & Cryptorchidism & $\begin{array}{l}\text { Redundant } \\
\text { skin on the } \\
\text { neck, arm } \\
\text { and back } \\
\text { neonatal } \\
\text { death }\end{array}$ \\
\hline Ogle et al.1996 [14] & p15.2q35 & $\begin{array}{l}\text { Consistent to } \\
\text { the WHS } \\
\text { high forhead } \\
\text { broad nasal } \\
\text { bridge } \\
\text { downslanting } \\
\text { palpebral fissures } \\
\text { abnormal ears }\end{array}$ & $\begin{array}{l}\text { Growth retardation } \\
\text { development delay } \\
\text { intelectual disability }\end{array}$ & Small VSD & $\begin{array}{l}\text { Thoracic } \\
\text { scoliosis } \\
\text { joint } \\
\text { contractures } \\
\text { abnormal } \\
\text { fingers }\end{array}$ & $\begin{array}{l}\text { Secondary sexual } \\
\text { characteristics were } \\
\text { underdeveloped, the } \\
\text { left testis was in the } \\
\text { scrotum and } \\
\text { hypoplastic, and the } \\
\text { right undescended. }\end{array}$ & Live \\
\hline Mun et al. 2010 [15] & p16q31.3 & No & Mild growth retardation & No & No & No & Live \\
\hline Dufke et al. 2000 [16] & p16.2q35.1 & $\begin{array}{l}\text { Consistent to WHS } \\
\text { high forehead } \\
\text { hypertelorism } \\
\text { broad nasal bridge } \\
\text { dolichocephaly }\end{array}$ & Growth retardation & No & No & No & Live \\
\hline $\begin{array}{l}\text { Malvestiti et al. } \\
2013 \text { [17] }\end{array}$ & p16.3q35.2 & $\begin{array}{l}\text { Hypertelorism } \\
\text { prominent eyes } \\
\text { low-set ears } \\
\text { beaked nose } \\
\text { small chin }\end{array}$ & $\begin{array}{l}\text { Intrauterine } \\
\text { growth retardation }\end{array}$ & No & No & No & $\begin{array}{l}\text { Terminated } \\
\text { at } 20 \text { weeks } \\
\text { of gestation }\end{array}$ \\
\hline Our fetus 1 & p15.2q32.3 & NA & $\begin{array}{l}\text { Intro uterine } \\
\text { growth retardation }\end{array}$ & No & No & No & $\begin{array}{l}\text { Increased } \\
\text { NT, ascites, } \\
\text { terminated at } \\
24 \text { weeks of } \\
\text { gestation }\end{array}$ \\
\hline Dup $4 p$ and del $4 q$ & 10 cases & & & & & & \\
\hline $\begin{array}{l}\text { Hirsch et al.1993, } \\
\text { [11] patient II-5 }\end{array}$ & p15.32q35 & $\begin{array}{l}\text { Unilateral ptosis } \\
\text { facial asymetry } \\
\text { prominent ears } \\
\text { with abnormal } \\
\text { helices }\end{array}$ & $\begin{array}{l}\text { Mental retardation } \\
\text { but was reported to be } \\
\text { caused by birth asphyxia }\end{array}$ & No & $\begin{array}{l}\text { Congenital hip } \\
\text { dis-location } \\
\text { and scoliosis }\end{array}$ & No & Live \\
\hline
\end{tabular}


Table 1 clinical presentations of two types of recombinants (Continued)

\begin{tabular}{|c|c|c|c|c|c|c|c|}
\hline \multirow[t]{2}{*}{ Authors } & \multirow[t]{2}{*}{ Sub-bands } & \multicolumn{5}{|l|}{ Clinicalpresentations } & \multirow{2}{*}{$\begin{array}{l}\text { Outcome and } \\
\text { annotations }\end{array}$} \\
\hline & & $\begin{array}{l}\text { Facial } \\
\text { dysmorphisism }\end{array}$ & $\begin{array}{l}\text { Growth and } \\
\text { development/mental delay }\end{array}$ & $\mathrm{CHD}$ & $\begin{array}{l}\text { Extremities } \\
\text { abnormailities }\end{array}$ & $\begin{array}{l}\text { Genital } \\
\text { abnormalities }\end{array}$ & \\
\hline $\begin{array}{l}\text { Battaglia } \\
\text { et al. 2002 [5] }\end{array}$ & p14q35.1 & $\begin{array}{l}\text { Mild ptosis, } \\
\text { upturned nose, } \\
\text { thin upper lip } \\
\text { prominent ears } \\
\text { with a mild cupped } \\
\text { configuration }\end{array}$ & Growth delay & $\begin{array}{l}\text { Congenital heart } \\
\text { defectbut } \\
\text { not } \\
\text { mentioned } \\
\text { in detail }\end{array}$ & $\begin{array}{l}\text { Short fingers } \\
\text { with } \\
\text { transverse } \\
\text { creases, } \\
\text { abnormal toe, } \\
\text { coccyx dimple }\end{array}$ & $\begin{array}{l}\text { Underdeveloped } \\
\text { scrotum }\end{array}$ & Live \\
\hline $\begin{array}{l}\text { Garcia-Heras } \\
\text { et al. } 2002 \text { [18] }\end{array}$ & p15q35 & $\begin{array}{l}\text { Microcephaly } \\
\text { prominent forhead } \\
\text { shallow orbit } \\
\text { midface dysplasia } \\
\text { small chin }\end{array}$ & $\begin{array}{l}\text { Growth and } \\
\text { develoment delay }\end{array}$ & $\begin{array}{l}\text { Pulmonary } \\
\text { hypertension } \\
\text { and PDA }\end{array}$ & No & No & Live \\
\hline $\begin{array}{l}\text { Stembalska et al. } \\
2007 \text { [19] patient1 }\end{array}$ & p14q35 & $\begin{array}{l}\text { Microcephaly } \\
\text { abnormal ears } \\
\text { with cupped } \\
\text { configuration } \\
\text { broad nose } \\
\text { short neck }\end{array}$ & $\begin{array}{l}\text { Growth and } \\
\text { development delay }\end{array}$ & No & Short fingers & No & Live \\
\hline $\begin{array}{l}\text { Stembalska et al. } \\
2007 \text { [19] patient } 2\end{array}$ & p14q35 & $\begin{array}{l}\text { Microcephaly } \\
\text { abnormal ears } \\
\text { with cupped } \\
\text { configuration } \\
\text { broad nose } \\
\text { short neck }\end{array}$ & $\begin{array}{l}\text { Growth and } \\
\text { development delay }\end{array}$ & No & Short fingers & No & Live \\
\hline $\begin{array}{l}\text { Maurin et al. } \\
2009[20]\end{array}$ & p15.1q35.1 & $\begin{array}{l}\text { Anteverted nose } \\
\text { large philtrum } \\
\text { downslanting } \\
\text { palperbral fissure } \\
\text { thin upper lip } \\
\text { short neck }\end{array}$ & $\begin{array}{l}\text { Growth and } \\
\text { development delay }\end{array}$ & $\begin{array}{l}\text { Interauricular } \\
\text { septal defect }\end{array}$ & $\begin{array}{l}\text { Mild edema } \\
\text { of feet }\end{array}$ & No & Live \\
\hline $\begin{array}{l}\text { Hemmat et al. } \\
2013[7]\end{array}$ & p15.1q35.1 & $\begin{array}{l}\text { Microcephly } \\
\text { broad nose with } \\
\text { anteverted nares } \\
\text { thin upper lip } \\
\text { abnormal ears } \\
\text { short neck }\end{array}$ & Developmental delay & $\begin{array}{l}\text { Congenital heart } \\
\text { disease but not } \\
\text { mentioned in } \\
\text { detail }\end{array}$ & No & $\begin{array}{l}\text { Yes but not } \\
\text { mentioned } \\
\text { in detail }\end{array}$ & Live \\
\hline $\begin{array}{l}\text { Tassano et al. } \\
2012[8]\end{array}$ & $\begin{array}{l}\text { p15.1q35.1 } \\
\text { (de novo) }\end{array}$ & $\begin{array}{l}\text { Hypertelorism } \\
\text { prominnet ears } \\
\text { with cupped } \\
\text { configuration } \\
\text { saddle nose } \\
\text { thin upper lip } \\
\text { retrognathia } \\
\text { short neck }\end{array}$ & $\begin{array}{l}\text { Growth and } \\
\text { development delay }\end{array}$ & No & $\begin{array}{l}\text { Congenital } \\
\text { lucation of } \\
\text { the right hip } \\
\text { bilateral } \\
\text { clubfeet }\end{array}$ & No & Live \\
\hline $\begin{array}{l}\text { Decipher Patient } \\
\text { ID } 269158\end{array}$ & p15.3q34.2 & $\begin{array}{l}\text { Prominent } \\
\text { forhead }\end{array}$ & $\begin{array}{l}\text { Developmental } \\
\text { delay }\end{array}$ & ASD & NA & NA & Live \\
\hline Our fetus 2 & p15.2q32.3 & NA & No & $\begin{array}{l}\text { VSD } \\
\text { overriding aorta } \\
\text { persistent trunk }\end{array}$ & No & No & $\begin{array}{l}\text { Terminated } \\
\text { at } 24 \text { weeks } \\
\text { of gestation }\end{array}$ \\
\hline
\end{tabular}

No no such clinical manifestation was present, NA not available, CHD congenital heart disease, VSD ventricular septal defect, PDA Patent ductus arterious, ASD Atria septal defect

Ten cases in upper part of Table 1 harbered the recombinant type of Dup 4q and del $4 p$. Ten cases in lower part of Table 1 harbered the the recombinant type of Dup $4 p$ and del $4 q$

noting that, not all rec (4) syndrome cases were derived from the parental pericentric inversion of chromosome 4. Tassano et al. [8] reported the first de novo rec (4) syndrome case with dup 4p at p15.1 and del 4q at q35.1 in 2012. Besides the possibility of the presence of a cryptic inversion undetectable by classical cytogenetic or FISH analysis on one chromosome 4 of the parents, the second possible mechanism might be that inverted low copy repeats in the same chromosome arm form a partial folding of one homologue onto itself with a recombination event between the inverted repeats. The pre-meiotic double-strand breaks with subsequent fusion between sister chromatids was also the third possible mechanism that they suggested $[6,8]$. In addition to these hypothesizes, harboring chromosome 4 inversion gametes because of germline mosaicism should also been considered. 
The clinical phenotype of rec (4) has been a subject of debate for years. Although previous studies have conducted the genotype-phenotype correlation of rec (4) syndrome, the results were contradictory, with some authors suggested that rec (4) syndrome appears to be an entity which can be suspected on the basis of specific clinical features [5, 7], while others argued that rec (4) syndrome is not characterized by a recognizable phenotype [18]. The previous studies were unable to point out the genotype-phenotype relationship because they described the rec (4) syndrome as an entirety. We recommend classifying it into two categories according to its two recombinant types: dup $4 \mathrm{p}$ with del $4 \mathrm{q}$, and dup $4 \mathrm{q}$ with del $4 \mathrm{p}$, in order to better describe the genotype-phenotype correlation.

The clinical manifestations of rec (4) cases with dup $4 \mathrm{q}$ and del $4 \mathrm{p}$ are consistent with WHS, i.e., $4 \mathrm{p}$ - syndrome. There were 10 cases with dup $4 \mathrm{q}$ and del $4 \mathrm{p}$ through literature review (shown in the upper part of Table 1). All cases presented with an apparent "Greek Warrior Helmet appearance", which is a typical clinical feature of WHS, including prominent forehead, flat and broad nasal bridge, hypertelorism, small chin, epicanthic folds, etc. All cases presented with different degrees of growth retardation and development delay, even the prenatal case, our case 1 presented early onset intrauterine growth retardation. Growth retardation and development delay are also the most common clinical features of WHS. The incidence of congenital heart disease in patients with recombinant type of dup $4 \mathrm{q}$ and del $4 \mathrm{p}$ in Table 1 was approximately $30 \%$, which is similar to WHS patients [22, 23].We proposed that the main clinical features of rec (4) cases with dup 4q and del 4p were caused by $4 \mathrm{p}$ deletion, rather than $4 \mathrm{q}$ duplication. The expression effect of the $4 p$ deletion might be stronger than that of some simultaneous partial duplication. Some authors observed that patients with a very small 4 p16.3 deletion combined with a large concomitant duplication of proximal segment of short arm of chromosome 4 presented with typical WHS clinical features [24, 25]. In Table 1, the two patients in Dufke and Malvestiti et al.'s studies carried a large 4q duplication with a very small $4 \mathrm{p}$ deletion. Both patients presented with typical WHS clinical manifestations $[16,17]$. Our findings provided more evidence to support the opinion of "stronger gene effect of $4 \mathrm{p}$ deletion" .

The craniofacial dysmorphisms in cases with dup $4 \mathrm{p}$ and del $4 \mathrm{q}$ are not very consistent (10 cases shown in the lower part of Table 1). However, the prominent clinical manifestation among these patients is the high incidence of congenital heart disease (CHD). Six of 10 cases presented with CHD, giving a very high incidence of 60\% (including the Decipher patient 269,158 and our fetus 2$)[5,7,18,20]$. It has been reported that pure $4 p$ terminal duplications with the same size on short arm of chromosome 4 seldom give rise to CHD [2]. However, cases with pure $4 \mathrm{q}$ terminal deletions or rec (4) cases with dup $4 \mathrm{p}$ and del $4 \mathrm{q}$ have much higher incidence of CHD (approximately 50\%) [2, 7]. Our data provide supporting evidence that $4 \mathrm{q}$ terminal might be a candidate region involved in heart development. The smallest overlapping region (SOR) of the six CHD cases is the $4 \mathrm{Mb}$ region proximal to the telomere on the long arm of chromosome 4 (sub-band of 4q35.2). There are five Ref Genes encompassed in the SOR, including FAT1, ZFP42, TRIML2, FGR1 and DBET. We suggest FAT1 might be the putative gene associated with cardiovascular development. According to the Project of Tissue-specific circular RNA induction of human fetal development, this gene presents much higher level of expression in fetal heart as early as 10 weeks of gestation, compared with other organs. This gene also expresses high levels in aorta and coronary arteries. Although there are no reports concerning correlation between FAT1 and cardiovascular disease, some authors found Fat1 may control vascular smooth muscle cell functions by facilitating migration and limiting proliferation [26]. It has been reported that FAT1intracellular domain can interact with multiple mitochondrial proteins and regulate cell growth and metabolism [27]. The facts of its high expression levels in fetal heart as well as its ability to regulate mitochondrial function led us propose FAT1 to be a candidate gene involved in cardiovascular development.

\section{Conclusions}

The present study showed a novel breakpoint on the long arm of chromosome 4 among the rec (4) syndrome cases. Genotype-phenotype correlation analysis reveals that the clinical manifestations of rec (4) cases with dup $4 q$ and del $4 p$ resemble those of WHS. High incidence of congenital heart disease is an obvious feature among dup $4 \mathrm{p}$ and del $4 \mathrm{q}$ cases, suggesting the putative association of 4q35.2 deletion with cardiovascular disease.

\section{Acknowledgements \\ We thank for the great help from technicians in Genetic Laboratory in International Peace Maternity \& Child Health Hospital.}

\section{Funding}

This work was supported by the National Natural Science Foundation of China (81370727 and 81501256).

Availability of data and materials

All data were presented and available in main paper and Additional files.

\section{Authors' contributions}

WY, LCM, GL, HWJ, ZY and WS performed the literature review, WY wrote the manuscript. WYL and ZXR collected the clinical cases. WSW and CWW are responsible for the content. YXY and $\mathrm{HBW}$ are responsible for the molecular and cytogenetic analysis. All authors read and approved the final manuscript. 


\section{Ethics approval and consent to participate}

This study has been approved by ethics boards of International Peace Maternity \& Child Health Hospital. Patient provided written informed consents before taking invasive procedure.

\section{Consent for publication}

Informed consents can be supplied.

\section{Competing interests}

The authors declare that they have no competing interests.

\section{Publisher's Note}

Springer Nature remains neutral with regard to jurisdictional claims in published maps and institutional affiliations.

\section{Author details}

'Prenatal Diagnostic Center, International Peace Maternity \& Child Health Hospital, School of Medicine, Shanghai JiaoTong University, Shanghai, China. ${ }^{2} \mathrm{OMNN}$ Research Group, Department of Obstetrics and Gynecology, Faculty of Medicine, University of Ottawa, Ottawa, Canada. ${ }^{3}$ Clinical Epidemiology Program, Ottawa Hospital Research Institute, Ottawa, Canada. ${ }^{4}$ School of Epidemiology \& Public Health, Faculty of Medicine, University of Ottawa, Ottawa, Canada. ${ }^{5}$ Department of Reproductive Genetics, International Peace Maternity \& Child Health Hospital, School of Medicine, Shanghai Jiao Tong University, Shanghai, China. ${ }^{6}$ Central laboratory, International Peace Maternity \& Child Health Hospital, Shanghai JiaoTong University School of Medicine, Shanghai, China.

Received: 21 June 2018 Accepted: 3 August 2018

Published online: 22 August 2018

\section{References}

1. Ho KS, South ST, Lortz A, et al. Chromosomal microarray testing identifies a $4 p$ terminal region associated with seizures in Wolf-Hirchhorn syndrome. J Med Genet. 2016:53:256-63.

2. Vona B, Nanda I, Neuner C, et al. Terminal chromosome $4 \mathrm{q}$ deletion syndrome in an infant with hearing impairment and moderate syndromic features : review of literature. BMC Med Genet. 2014;15:1-7.

3. Beaujard MP, Jouannic JM, Bessières $B$, et al. Prenatal detection of a de novo terminal inverted duplication $4 p$ in a fetus with the wolf-Hirschhorn syndrome phenotype. Prenat Diagn. 2005;25:451-5.

4. Cernakova I, Kvasnicova M, Lovasova Z, et al. A duplication dup (4) (q28q35. 2) de novo in a newborn. Biomed Pap Med Fac Univ Palacky Olomouc Czech Repub. 2006;150:113-6.

5. Battaglia A, Brothman AR, Carey JC. Recombinant 4 Syndrome Due to an Unbalanced Pericentric Inversion of Chromosome 4. Am J Med Genet. 2002; 106:103-6.

6. Zuffardi O, Bonaglia M, Ciccone R. Inverted duplications deletions: underdiagnosed rearrangements ? Clin Genet. 2009;75:505-13.

7. Hemmat M, Hemmat O, Anguiano A, et al. Genotype-phenotype analysis of recombinant chromosome 4 syndrome : an array-CGH study and literature review. Mol Cytogenet. 2013;6:2-6.

8. Tassano E, Alpigiani MG, Salvati $P$, et al. Molecular cytogenetic characterization of the first reported case of an inv dup (4p) (p15.1-pter ) with a concomitant 4q35.1-qter deletion and normal parents. Gene. 2012; 511:338-40.

9. Narahara K, Himoto Y, Yokoyama Y, et al. The critical monosomic segment involved in 4p- syndrome: a high-resolution banding study on five inherited cases. Jinrui Idengaku Zasshi. 1984;9:403-13.

10. de la Flor Bru J, Guiltart M. Wolf's syndrome due to pericentric inversion of maternal chromosome 4. An Esp Pediatr. 1987;27:205-7.

11. Hirsch B, Baldinger S. Pericentric inversion of chromosome 4 giving rise to dup ( $4 p$ ) and dup ( $4 q$ ) recombinants within a single kindred. Am J Med Genet. 1993:45:5-8.

12. Wolf G, Mao J, Izquierdo L. Paternal pericentric inversion of chromosome 4 as a cause of recurrent pregnancy loss. J Med Genet. 1994;31:153-5.

13. Villa A, Urioste M, Mc C, et al. Pericentric inversions of chromosome 4 : report of a new family and review of the literature. Clinc Genet. 1995:48:255-60.

14. Ogle R, Sillence DO, Merrick A, et al. The wolf-Hirschhorn syndrome in adulthood: evaluation of a 24-year-old man with a rec (4) chromosome. Am J Med Genet. 1996;65:124-7.
15. Mun SJ, Cho EH, Chey MJ, et al. Recombinant chromosome 4 with partial $4 p$ deletion and $4 q$ duplication inherited from paternal pericentric inversion Korean J Lab Med. 2010;30:89-91.

16. Dufke A, Eggermann K, Balg S, et al. A second case of inv (4) pat with both recombinants in the offspring: rec dup (4q) in a girl with wolf-Hirschhorn syndrome and rec dup (4p). Cytogenet Cell Genet. 2000;91:85-9.

17. Malvestiti F, Benedicenti F, De Toffol S, et al. Case report recombinant chromosome 4 from a familial Pericentric inversion : prenatal and adulthood wolf-Hirschhorn phenotypes. Case Rep Genet. 2013;2013:306098.

18. Garcia-heras J, Martin J. A rec (4) dup $4 p$ inherited from a maternal inv (4) (p15q35 ): case report and review. Am J Med Genet. 2002;230:226-30.

19. Stembalska A, Laczmanska I. Recombinant chromosome 4 resulting from a maternal pericentric inversion in two sisters presenting consistent dysmorphic features. Eur J Pediatr. 2007;166:67-71.

20. Maurin ML, Labrune $P$, Brisset $S$, et al. Molecular cytogenetic characterization of a 4p15.1-pter duplication and a 4q35.1-qter deletion in a recombinant of chromosome 4 pericentric inversion. Am J Med Genet Part A. 2007;149:226-31.

21. Griffiths AJF, Gelbart WM, Miller JH, et al. Modern genetic analysis. New York: W. H. Freeman; 1999.

22. Maas NM, Van Buggenhout G, Hannes F, et al. Genotype-phenotype correlation in 21 patients with wolf-Hirschhorn syndrome using high resolution array comparative genome hybridisation $(\mathrm{CGH})$. J Med Genet. 2008:45:71-80.

23. Battaglia A, Carey JC, South ST. Wolf-Hirschhorn syndrome: a review and update. Am J Med Genet C Semin Med Genet. 2015;169:216-23.

24. Piccione M, Salzano E, Vecchio D, et al. 4p16.1-p15.31 duplication and 4p terminal deletion in a 3-years old Chinese girl: Array-CGH, genotypephenotype and neurological characterization. Eur J Paediatr Neurol. 2015;19: 477-83.

25. Kondoh Y, Toma T, Ohashi H, et al. Inv dup del (4) (:p14 --> p16.3::p16.3 --> qter) with manifestations of partial duplication $4 p$ and Wolf-Hirschhorn syndrome. Am J Med Genet A. 2003;120A:123-6.

26. Hou R, Liu L, Anees S, et al. The Fat1 cadherin integrates vascular smooth muscle cell growth and migration signals. J Cell Biol. 2006;173:417-29.

27. Cao LL, Riascos-Bernal DF, Chinnasamy P, et al. Control of mitochondrial function and cell growth by the atypical cadherin Fat1. Nature. 2016;539:575-8.
Ready to submit your research? Choose BMC and benefit from:

- fast, convenient online submission

- thorough peer review by experienced researchers in your field

- rapid publication on acceptance

- support for research data, including large and complex data types

- gold Open Access which fosters wider collaboration and increased citations

- maximum visibility for your research: over $100 \mathrm{M}$ website views per year

At BMC, research is always in progress.

Learn more biomedcentral.com/submissions 